\title{
Możliwości i ograniczenia kreowania teorii polityki
}

\section{The Potential and Limitations of Creating the Theory of Politics}

\begin{abstract}
Long term comparative studies on the specificity of the multifaceted character of politics, politicization and politicality - entailing both political thought of various ideological currents and thus different axiological interpretations, and also fundamental political notions - should aim to formulate general statements earning the status of significant explanatory and nomological conclusions, which are instrumental in creating specific political theories.

Comparative experience in nomological explanation of political phenomena and processes, and also various idiosyncrasies of politicality should enable a political ideation that would contribute to a creative expression of theoretical statements in terms of regularities understood in a probabilistic sense, referring to broadly-understood politics, verifiable in constantly-changing social and political circumstances.

It is recommended that efforts to formulate an optimally adequate conceptual paradigm in terms of theory of politics are intensified. As a result, there would appear various proposals of a theory of politics that would correspond to socio-political reality, the theory that should be complementary to numerous sub-fields in political science. Their exponents can express, to a greater or lesser extent, a wish to formulate observations that will become statements with a status similar to that of theoretical ones, which are complementary to investigations and explanations in the area of broadly-understood political research.
\end{abstract}

Keywords: explanation, politics, theory of politics, interdisciplinarity, political studies

\section{Status nauk o polityce w sytuacji apoteozy bądź krytyki interdyscyplinarności specjalności politologicznych}

Za oczywiste należy uznać stwierdzenie, iż relatywnie nowe dyscypliny z zakresu nauk humanistyczno-społecznych i ich poszczególne subdyscypliny wywodzą się z wcześniej zaistniałych i ugruntowanych dyscyplin poznawczych. Doty- 
czy to również dyscypliny poznawczej z zakresu nauk społecznych zwanej często „naukami politycznymi”, a od ćwierćwiecza w Polsce naukami o polityce, czy też nierzadko politologią w znaczeniu szerokim. Dyskusja w tej kwestii nie wydaje się zakończona (Janusz, 2015, s. 44-49).

Można sądzić, iż nazwa dyscypliny nauki o polityce implikuje sugestię, że ta refleksja naukowo-badawcza - której zasadniczy „trzon” określa się mianem politologii ${ }^{1}$ sensu stricto - jest nierzadko uznana za swego rodzaju „zlepek” licznych subdyscyplin humanistyczno-społecznych, które koncentrują się na zainteresowaniu problematyką polityki, w tym także polityzacją i „politycznością" i które mniej lub bardziej uobecniają się w przestrzeni publicznej. Sprzyja to pojawianiu się tendencji do interpretacji rozszerzonej w odniesieniu do nazwy „nauki o polityce", wskutek czego wyrażane są niekiedy opinie, iż niejasna jest tożsamość poznawcza, eksplanacyjna, kategorialna i metodologiczna tej dyscypliny naukowej. W związku z tym preferuje się dość usilnie, a także w sposób poniekąd „hasłowy" postulaty interdyscyplinarności, a nawet multidyscyplinarności nauk o polityce, co do których nie zawsze wiadomo, jaki jest ich kontekst znaczeniowy. Stąd też teksty określane jako naukowe nie zawsze mogą być w pełni uznawane za te, które odpowiadają kryteriom, jakie wyznaczają wymogi stawiane naukom o polityce. Niełatwo jest $\mathrm{w}$ tych tekstach dostrzec uobecniającą się wyraźnie „dominantę politologiczną". Z tego względu nie zawsze można zauważyć klarowność w zakresie politologicznego podejścia metodologicznego, które wyznaczałoby odpowiedni styl wyjaśniania nomologicznego w naukach o polityce ${ }^{2}$.

Przyjęcie odpowiedniej formuły w zakresie refleksji naukowej, której przedmiotem są takie lub inne realia polityczne, $\mathrm{w}$ tym również zjawiska polityzacji i polityczności, nie musi być jednoznaczne ze skłonnością do badań interdyscyplinarnych, a nawet multidyscyplinarnych prowadzonych przez specjalistów utożsamiających się z dyscypliną naukową o nazwie nauki o polityce, a zatem $\mathrm{z}$ - politologią sensu largo. W ramach nauk o polityce dochodzi do zapożyczania $\mathrm{z}$ wielu nauk humanistyczno-społecznych aparatu pojęciowego, metod badawczych i sposobu wyjaśniania oraz stylu narracji (Wallas, 2015, s. 252-272). W związku z tym nie traci na aktualności stwierdzenie, iż należy być świadomym „osobliwości nauk społecznych", także humanistycznych (Ossowski, 1983, s. 33, 162).

Okazuje się że stosunek do problemu interdyscyplinarności - jako ważnego postulatu badawczego $w$ naukach humanistyczno-społecznych, w tym również

Truizmem jest stwierdzenie, iż politologia to „nauka o polityce” (podkreślmy: w liczbie pojedynczej).

2 Autor niniejszego szkicu korzysta $\mathrm{z}$ wiedzy zaczerpniętej $\mathrm{z}$ wielu nauk humanistyczno-społecznych, w tym przede wszystkim politologicznej oraz z własnego doświadczenia naukowego w zakresie badania myśli politycznej, a także metodyczno-warsztatowego w zakresie niektórych zagadnień teoretyczno-politycznych. 
w zakresie dyscypliny o nazwie nauki o polityce, jest ostatnio w Polsce nader doniosłą kwestią wzbudzającą niemałe kontrowersje. Nic więc dziwnego, iż dyskusja naukowa dotycząca tej kwestii nabiera coraz bardziej polemicznego, a nawet wyraźnie spolaryzowanego charakteru (Skarzyński, 2012). Z tego względu narosło sporo nieporozumień, objawiających się w wyrażaniu stanowisk nierzadko krańcowych, którym towarzyszą niekiedy - niezależnie od naukowej, a zatem racjonalnej argumentacji - także subiektywne opinie artykułowane $\mathrm{z}$ jednej strony przez zwolenników i entuzjastów interdyscyplinarności, a z drugiej strony przez jej nieprzejednanych przeciwników (Hudzik, 2014, s. 258-264, 278).

Admiratorzy owych przeciwstawnych opcji dotyczących nauk o polityce formułują konstatacje w sposób jednoznaczny, a nawet bezalternatywny, co bywa niekiedy następstwem subiektywnych odczuć, gdy uwzględnia się postulat na rzecz interdyscyplinarności, nierzadko ujmowany w sposób nie w pełni klarowny. Stąd też nader znamienne jest deklaratywno-werbalne podejście do interdyscyplinarności, które nie zawsze znajduje odzwierciedlenie w postępowaniu badawczym, zwłaszcza w eksplanacji poznawczej oraz w stosownej narracji, co przejawia się niekiedy w preferowaniu określonego stylu refleksji naukowej jako „jedynie słusznej”. Toteż nietrudno nie zgodzić się z przeświadczeniem, iż interdyscyplinarności w naukach humanistyczno-społecznych nie powinno się pojmować w sposób „mechaniczny”, czy też jako deklaracji na rzecz niekoherentnego łączenia różnych tematyk oraz podejść badawczych i „poetyk” narracyjnych w zakresie nauk o polityce. Może to powodować pojawienie się zjawiska hybrydyzacji nauk o polityce oraz eklektyzacji w podejściu do przedmiotu badań i w sposobie formułowania pytań problemowych, a także w wyjaśnianiu i stylu narracji naukowej (Trzebiński, 2002).

Stosowne postępowanie konceptualne na rzecz wykreowania klarownej tożsamości poznawczej i metodologicznej dyscypliny o nazwie nauki o polityce, która bywa często określana mianem politologii sensu largo, jest ze wszech miar ważne. Niektórzy zwolennicy stricte monodyscyplinarnego podejścia poznawczego do politologii zdecydowanie odrzucają wszelkie tendencje interdyscyplinarne. Stąd też deklarowane jest przeświadczenie, iż możliwe staje się wykreowania niejako „czystej” formuły poznawczej w badaniach politologicznych, „nieskażonej” jakąkolwiek interdyscyplinarnością. Tego rodzaju przekonanie sugeruje pytania poniekąd retoryczne: czy w ogóle istnieją jakieś „czyste”, a więc optymalne „nieinterdyscyplinarne" nauki humanistyczno-społeczne, jak chociażby socjologia, etnologia, filologia, prawoznawstwo i historiografia (Braudel, 1999, s. 46-49).

Odpowiedź na to pytanie, po pierwsze, może się sprowadzać do aprobaty przeświadczenia, iż preferowanie bezalternatywnej formuły w kwestii konieczności zupełnego odrzucenia interdyscyplinarności jest podejściem nie tylko niekreatywnym pod względem poznawczym, ale także poniekąd utopij- 
nym. Niemniej jednak nie zawsze politolodzy, oczywiście z wielu różnych przyczyn, posługują się pojęciami znanymi i typowymi dla innych nauk humanistyczno-społecznych. Pojawia się również niechęć do przyswojenia właściwych im podejść metodologicznych i eksplanacyjnych na gruncie "nauk o polityce”. W związku z tym za ważne należy uznać pytanie: jakie są granice nauk o polityce (Wojtaszczyk, 2015, s. 51-63; Ulicka, 2015, s. 99-118).

Po drugie, deklaratywno-werbalne przekonanie o potrzebie podejścia interdyscyplinarnego może rzeczywiście osłabić tożsamość poznawczą, czy też szerzej - metodologiczną, nauk o polityce i wskutek tego spowodować eklektyzację tej dyscypliny naukowej.

Ograniczanie się nauk o polityce wyłącznie do tego, co jest specyficzne dla politologii sensu stricto, może doprowadzić do pojawienia się rutynizacji poznawczej i - w następstwie tego - stagnacji badawczej tej dyscypliny nauk społecznych. Nie można się zatem dziwić, iż z tego względu aprobowane bywa przez politologów przeświadczenie, że badania w zakresie nauk o polityce, uwzględniające - o ile to jest niezbędne - podejście interdyscyplinarne o znamionach kreatywnych, nie musi oznaczać rezygnacji z potrzeby uznawania dominującej roli wyraźnie dostrzeganych merytorycznych atrybutów politologicznych (Ponczek, 2016, s. 79-99).

\section{Badania w zakresie myśli politycznej a możliwości teoretycznej refleksji w kwestii osobliwości polityki, polityzacji i polityczności}

Naukowiec zajmujący się w wymiarze badawczym problematyką polityki i utożsamiający się z podejściem politologicznym, a także podejmujący badania w zakresie myśli politycznej powinien zapoznać się z szerszym spektrum podejść do przedmiotu poznania, którym są rozmaite osobliwe emanacje formuł ideologiczno-politycznych. Stąd też niezbędne okazuje się uwzględnienie odpowiednich podejść badawczych w zakresie myśli politycznej typowych dla wielości dyscyplin i specjalności nauk humanistyczno-społecznych. Możliwość stosowania tych podejść w procedurze poznawczej jest przydatna w trakcie pogłębionej analizy badawczej wielości nurtów myśli politycznej i wyjaśniania ich imponderabiliów. Oznacza to, iż badacz myśli politycznej powinien reprezentować postawę otwartą na różne inspiracje poznawcze, co wymagałoby akceptacji nastawienia kreatywnego. Sprzyjałoby to śledzeniu osiągnięć w zakresie badań szeroko rozumianej myśli politycznej, a nawet więcej - społeczno-politycznej, łącznie z odniesieniami filozoficznymi, socjologicznymi, ekonomicznymi, prawoznawczymi, historiozoficznymi oraz - co jest oczywiste - w zakresie historii idei. Wniknięcie $\mathrm{w}$ owe inspiracje poznawczo-eksplanacyjne i metodologiczne powinno ułatwić 
szeroki, pogłębiony i innowacyjny ogląd, a także adekwatną eksplanację problematyki myśli politycznej. Umożliwiłoby to uzyskanie odpowiedzi na pytania:

- Jaki jest jej sens ontologiczny myśli politycznej i jej odniesień aksjologicznych?

- W jakim zakresie klarowna i pogłębiona myśl polityczna integruje jakąś teorię polityki?

Uświadomienie sobie istnienia i funkcjonowania wielości „opcji” poznawczych myślenia politycznego oraz ujęć w zakresie wyjaśniania osobliwości jego imponderabiliów może się przyczynić do pogłębionego poznania różnych orientacji aksjologicznych w tym zakresie oraz pozwolić na formułowanie stwierdzeń na relatywnie wysokim poziomie ogólności. Wzbogaceniem tego typu badań mógłby być wybór podejścia uwzględniającego dążenie do odtworzenia systemu wartości politycznych jako kwintesencji danego sposobu myślenia politycznego, a także rozpoznanie i odtworzenie specyficznie ujmowanych pojęć politycznych. Wskutek tego możliwe okazałoby się rozpoznanie zarówno tendencji co do typowości, oryginalności i intensywności, jak i incydentalności oraz impresyjności w sferze myślenia politycznego (Paruch, 2015, s. 157-173).

Nie zawsze badacze myśli politycznej są wystarczająco świadomi wyżej zarysowanych możliwości w zakresie procedury poznawczo-eksplanacyjnej. Niewątpliwie wyrazistą funkcję poznawczą spełniają „zakorzenione” przeświadczenia i swoiste "przyzwyczajenia” badawcze, które nie zawsze umożliwiają osiągnięcie pozytywnych i - co jest oczywiste - kreatywnych rezultatów poznawczych. Wielu politologom nie jest łatwo odrzucić różne przekonania i przyzwyczajenia, które nie sprzyjają prowadzeniu odkrywczych i innowacyjnych badań w zakresie myśli politycznej zwłaszcza w wymiarze komparatywnym (Paruch, 2004, s. 9-37).

Nie chodzi bynajmniej o wybór „wycinkowego” oglądu myśli politycznej, a więc z punktu widzenia jednej dyscypliny naukowej, lecz o aprobatę szerokiej i pogłębionej oraz wieloaspektowej analizy nomologicznej różnych refleksji politycznych, uwzględniającej w stosownym zakresie - o ile to jest niezbędne - podejście multidyscyplinarne. Spowodowałoby to pojawienie się $\mathrm{w}$ wymiarze poznawczym pozytywnych rezultatów twórczych $\mathrm{w}$ zakresie podjętych przedsięwzięć o charakterze naukowym, dotyczących refleksji teoretyczno-politycznej. Sprzyjałaby temu diachroniczna i holistyczna eksplanacja wielości nurtów aksjologicznych myślenia politycznego $\mathrm{z}$ uwzględnieniem w procedurze poznawczej różnych podejść badawczych oraz „poetyk” narracyjnych (Ponczek, 2015, s. 117-135).

Należy podkreślić, iż konstatacje formułowane przez badacza myśli politycznej aprobującego podejście komparatywne powinna cechować odporność na subiektywną recepcję oddziaływań ideologicznych o różnych proweniencjach, uważanych w takim lub innym czasie historycznym za „słuszne” bądź „niesłuszne”. Preferencje owe nie powinny wpływać na styl narracji i wskutek tego stymulować subiektyw- 
ną wykładnię oraz interpretację takiej lub innej postaci myśli politycznej. Na takie niebezpieczeństwo bywa niekiedy narażony badacz myśli politycznej jednego tylko nurtu ideologicznego, gdyż pojawia się tendencja do utożsamiania się z nim podmiotu poznającego. Owa tendencja może sprzyjać wyborowi woluntarystyczno-subiektywnego sposobu odtwarzania i prezentacji innych nurtów myśli politycznej. $Z$ tego względu byłoby wskazane respektowanie przez badacza myśli politycznej postulatu na rzecz zobiektywizowanego uwzględnienia i empatycznego zrozumienia tego, co głosili i nadal głoszą poszczególni kreatorzy myśli politycznej. Sprzyjałoby temu kierowanie się dystansem poznawczym, umożliwiającym wnikliwe wyjaśnienie istoty analizowanych poglądów politycznych (Klementewicz, 2010, s. 35-60).

W związku z powyższym za oczywistą należy uznać następująca dyrektywę: badacz myśli politycznej nie powinien być uwikłany pod względem personalnym w obecne spory ideologiczne oraz nie może on ulegać subiektywnym intencjom ze strony mocodawców politycznych i ekonomicznych, a zatem sponsorów wspierających określone badania naukowe. Chodzi o to, aby nie dochodziło do ograniczenia swobody badań oraz do rezygnacji z poczucia neutralności w zakresie analizy i eksplanacji przedmiotu poznania, którym jest myśl polityczna. Oznacza to, iż dążeniu do zobiektywizowanego i kompleksowego odtworzenia myśli politycznej nie może zagrażać podejście preferujące subiektywizm, a nawet woluntaryzm poznawczy (Nowak, 2014).

Z tego względu należy się kierować w największym stopniu intencją na rzecz kreatywnego uwzględniania oglądu opartego na decentracji interpersonalnej ${ }^{3}$. Toteż niezależnie od przyjętych podejść badawczych (Duszak, Fairclough, 2008) chodziłoby o to, aby na procedurę poznawczą w zakresie myśli politycznej nie wpływały dysfunkcjonalne tendencje sprzyjające jakiejkolwiek subiektywizacji jej oglądu, a także skłonności do daleko idącej relatywizacji poznawczej w zakresie podejść badawczych oraz wyjaśniania naukowego. Aby do tego nie doszło, potencjalni badacze myśli politycznej powinni się zapoznać z jej historiografią, co mogłoby sprzyjać przyjęciu otwartej i zarazem krytycznej postawy poznawczej.

Decentracja interpersonalna - postawa stanowiąca przeciwieństwo egocentryzmu. Chodzi o uobecnienie się w osobowości badacza czegoś, co określa się jako „poza-ja” i abstrahowanie od stanów emocjonalnych. Umożliwia to trafne poznawanie sposobu myślenia innych ludzi lub grup i zrozumienie odmiennego punktu widzenia. Osiągnięcie decentracji interpersonalnej w sferze poznania jest dość trudne, ponieważ wymaga odejścia od własnej subiektywizacji, a więc dystansu do niej (zob. Jerzmanowska, 2013, s. 67-79).

4 Zdarza się, iż naukowcy-debiutanci rozpoczynający badania myśli politycznej, czyli bez wystarczającej praktyki w tym zakresie, są nierzadko skłonni bezkrytycznie, czy też poniekąd w sposób mechaniczny kierować się niezbyt trafnymi postmodernistycznymi formułami metodologicznymi, które mogłyby sprzyjać adekwatnemu poznaniu, a więc eksplanacji myśli politycznej. Aprobata tego rodzaju formuł poznawczych mogłaby przyczyniać się do kwestionowania potrzeby badań w zakresie myśli politycznej (zob. Ponczek, 2015). 
Można sądzić, iż naukowcy zajmujący się odtwarzaniem myśli politycznej i wyjaśnianiem jej istoty powinni być skłonni uwzględniać dyrektywę na rzecz kierowania się odpowiednim „dystansem” poznawczym i podejściem komparatywnym pozwalającym na optymalnie neutralną eksplanację przedmiotu badań. Sprzyjałoby to tym badaczom w osiągnięciu niezbędnego poziomu abstrahowania umożliwiającego formułowanie optymalnie zobiektywizowanych uogólnień jako kwintesencji myśli politycznej (Kucharczyk, 2009, s. 6). W związku z tym w badaniu politologicznym myśli politycznej należałoby:

- posługiwać się swobodnie adekwatnymi kategoriami politologicznymi;

- analizować i wyjaśniać specyfikę myśli politycznej w ujęciu holistycznym i diachronicznym;

- wskazać na to, co jest typowe, i na to, co incydentalne bądź też okazjonalne, oraz to $\mathrm{w}$ jakim zakresie uobecnia się tendencja do kontynuacji lub odrzucenia określonego stylu myślenia politycznego;

- zdecydować się na nomologiczną narrację myśli politycznej, która nie musi oznaczać rezygnacji z możliwości zwrócenia uwagi na odpowiednią wiedzę szczegółową, a więc idiograficzną, przydatną pod względem eksplanacyjnym w tego rodzaju przedsięwzięciu badawczym;

- nie rezygnować z innych doświadczeń poznawczych dotyczących zwłaszcza: historii idei, historii doktryn polityczno-prawnych, myśli socjologicznej oraz myśli ekonomiczno-społecznej, ponieważ można je twórczo zaadaptować $\mathrm{w}$ trakcie politologicznego badania myśli politycznej;

- rozpoznać i odtworzyć hierarchię wartości określającą istotę myśli politycznej, niezależnie od pojawiających się w epoce współczesnej wielu poznawczych odmienności przedmiotu badań (Bäcker i in., 2008).

Tego rodzaju aktywność intelektualna dotycząca politologicznej eksplanacji myśli politycznej wymaga pogłębionej wiedzy metodologicznej w zakresie nauk społecznych, znacznego doświadczenia badawczego $\mathrm{w}$ poznawaniu wielorakich emanacji myślenia politycznego, a także wykazania się intencją na rzecz wieloaspektowego oraz wnikliwego i zobiektywizowanego oglądu osobliwości realiów polityki i refleksji na ich temat. Niezbędne jest zatem wykazanie się przez politologów umiejętnościami w zakresie dostrzegania specyfiki myślenia politycznego oraz intencji na rzecz podjęcia się wieloaspektowej analizy nomologicznej, uwzględniającej w stosownym zakresie - o ile to jest niezbędne - podejście interdyscyplinarne (zob. odmienne stanowisko Skarzyński, 2012, s. 147-159; 2014, s. 32-43, 70-73). Owe przedsięwzięcia konceptualne dotyczące pogłębionego rozpoznania aksjologicznego wielu ideologii i doktryn politycznych, a także synkretycznych emanacji myśli politycznej, przy uwzględnieniu podejścia komparatywnego i interdyscyplinarnego w stosownym zakresie, mogą sprzyjać kreowaniu hipotetycznych konstatacji o charakterze teoretycznym, ma- 
jących swoje odniesienia w poznawanych realiach politycznych (Hudzik, 2014, s. 257-264, 278).

Oznacza to, iż politolodzy podejmujący się innowacyjnej konceptualizacji uogólnień w zakresie teorii polityki mogą za punkt odniesienia uznać zarówno doniosłe wykładnie myśli politycznej, jak i wiedzę dotyczącą istoty polityki i wieloaspektowego jej funkcjonowania w różnych układach czasoprzestrzennych. Mogłyby wówczas powstać konstrukty myślowe komplementarne wobec określonych teorii polityki. Wskutek trwania procesu ideacyjnego, obejmującego kreację owych konstruktów myślowych, może dojść do formułowania w miarę odkrywczych pod względem poznawczym uogólnień teoretyczno-politycznych (Bonecki, 2011).

Wielu politologów zajmujących się badaniem myśli politycznej, o ile będzie ich cechowała postawa poszukująca i determinacja poznawcza, może się podjąć konceptualizacji swoich dociekań na coraz wyższym poziomie ogólności, co sprzyjałoby formułowaniu istotnych uogólnień politycznych o znamionach teoretycznych. Do tego przedsięwzięcia badawczego przysposabia niewątpliwie pogłębiony ogląd aksjologiczny myśli politycznej i jej holistyczno-diachroniczna eksplanacja nomologiczna, która powinna mieć także wymiar komparatywny i - o ile to jest niezbędne - interdyscyplinarny, zwłaszcza jeśli chodzi o posługiwanie się kategoriami politologicznymi i adekwatnymi metodami badawczymi. Może to sprzyjać rozpoznaniu wielorakich odniesień poznawczych dotyczących „świata polityki” oraz - tym samym - uobecniających się prawidłowości mających mniej lub bardziej charakter hipotetyczny. Oczywiste jest to, iż owych hipotez zakładających trafność poznawczą formułowanych prawidłowości dotyczących polityki oraz polityczności nie można uznawać niejako za "twarde”, a więc bezalternatywne, aksjomaty teoretyczne na gruncie politologii. Mogłoby to grozić absolutyzacją w zakresie preferowania ważnych uogólnień teoretyczno- politycznych, co przyczyniałoby się do „dogmatyzacji” stwierdzeń dotyczących prawidłowości w zakresie szeroko rozumianej polityki oraz polityczności (Blok, Kołodziejczak, 2015, s. 25-29).

Okazuje się zatem, iż politolodzy podejmujący się innowacyjnej konceptualizacji formuł teoretycznych dotyczących istoty oraz osobliwości sfery polityki, polityzacji i polityczności mogą za punkt odniesienia uznać nie tylko ustalenia w zakresie prawidłowości określających sens decyzji i działań politycznych oraz funkcjonalności procesów politycznych w różnych układach czasoprzestrzennych (Karwat, 2015a, s. 142-151), ale także uogólnienia będące rezultatem badania myśli politycznej. 


\section{Wielość teorii politycznych a możliwości konceptualne na rzecz teorii polityki}

Za teorię polityki można uznać hipotetyczny układ w miarę koherentnych uogólnień zakładających mniej lub bardziej prawdopodobną sprawdzalność odkrytych prawidłowości odnoszonych do realiów politycznych. Nie zawsze owe uogólnienia dotyczące sprawdzalności określonych prawidłowości, odpowiadających wielorakim osobliwościom polityki i emanacjom polityczności, mogą uzyskiwać wykładnię probabilistyczną sprzyjającą w pełni rozpoznaniu i wyjaśnianiu skomplikowanych sytuacji politycznych. Mogą być one jednak uwzględniane $\mathrm{w}$ trakcie podejmowania odpowiednich decyzji oraz $\mathrm{w}$ procesie implementowanej skuteczności działań politycznych.

W związku z powyższym stwierdzenia formułowane na dość wysokim poziomie ogólności $\mathrm{w}$ zakresie funkcjonalności najbardziej prawdopodobnych prawidłowości odnoszonych do praktyki politycznej mogą być uznane za istotny komponent takiej lub innej teorii politycznej. Ów komponent teorii politycznej może się okazać zarówno następstwem ideacyjnych konceptualizacji specyfiki realiów politycznych, jak i rezultatem komparatywnych badań w zakresie nomologicznej eksplanacji myśli politycznej. Oznacza to, że owe konstatacje mogą sprzyjać kreowaniu hipotez o znamionach teoretycznych, odnoszących się do osobliwości „świata polityki” (Krauz-Mozer, 2005, s. 52-69).

Niezbędna okazuje się zatem aktywność intelektualna na rzecz hipotetycznego wyodrębnienia precyzyjnie zdefiniowanych pojęć optymalnie koherentnych, a także racjonalnie rozpoznanych prawidłowości politycznych. Jeśli tego rodzaju refleksja konceptualna trwa przez dłuższy czas oraz dotyczy wielości emanacji struktur aksjologicznych myśli politycznej, a także imponderabiliów takich lub innych orientacji ideologiczno-politycznych, to tego rodzaju komparatywne doświadczenie analityczne i eksplanacyjne w odniesieniu do czasoprzestrzeni politycznej pozwala na formułowanie na relatywnie wysokim poziomie ogólności zdań odnoszonych do istoty polityki, polityzacji i polityczności (Karwat, 2015b, s. 40-48).

Oznacza to, iż aktywność eksplanacyjno-nomologiczna może prowadzić do artykułowania innowacyjnych uogólnień, stających się próbą sformułowania komparatywnej i koherentnej teorii politycznej. Uobecniające się konstatacje teoretyczno-polityczne powinny odznaczać się wysokim poziomem ogólności, tak aby zawierały hipotezy zakładające prawdopodobieństwo prawidłowości odnoszących się do sfery polityki, które byłyby weryfikowane przez praktykę polityczną. Sprzyjałoby to ideacji umożliwiającej formułowanie konstatacji na jeszcze wyższym poziomie ogólności. 
Politolodzy o różnych naukowych proweniencjach specjalizacyjnych oraz przygotowaniu merytorycznym i predyspozycjach poznawczych, a także inni przedstawiciele nauk humanistyczno-społecznych odwołujący się do wielorakich opcji metodologicznych, zajmujący się dogłębnym i komparatywnym odtwarzaniem myśli politycznej oraz jej nomologiczną eksplanacją, mogą w miarę swoich kompetencji aspirować do stawania się autorami publikacji zawierających konstatacje teoretyczno-polityczne komplementarne względem założeń konceptualnych wielu teorii politycznych przenikniętych niekiedy dążeniami do subiektywizacji, czy też nawet ideologizacji pewnych formuł podlegających określonej interpretacji. Pozytywne rezultaty w wymiarze poznawczym i wyjaśniającym mogą sprzyjać teoretycznej refleksji na rzecz formułowania konstatacji ujmujących złożoność ontologiczną „świata polityki”. Pozwoliłoby to wyjaśnić specyfikę i złożoność procesu politycznego łącznie ze zjawiskiem polityzacji i uobecniającej się polityczności w wielowymiarowej przestrzeni publicznej (Biały, 2012, s. 21-35).

Osiągnięcie pomyślnego rezultatu w zakresie tego rodzaju dociekań intelektualnych może sprzyjać formułowaniu komparatywnych tez i założeń, stanowiących punkt wyjścia do konceptualnej innowacyjności w zakresie kreowania teorii politycznych i jednocześnie dobrze sprawdzalnych w wymiarze implementacyjnym, zwłaszcza w sytuacji zmieniających się realiów politycznych. Pozwalałoby to na formułowanie stwierdzeń zawierających stosowne hipotezy dotyczące prawidłowości szeroko rozumianej polityki uobecniającej się w określonym czasie i miejscu. Wskutek tego dochodziłoby do wykreowania hipotetycznych teorii politycznych, które nie musiałyby się przyczyniać do aksjomatyzacji narracji politycznej, ponieważ podlegałyby permanentnej weryfikacji poznawczo-nomologicznej. Owe formuły teoretyczne dotyczące szeroko rozumianej polityki mogłyby stanowić, w mniejszym bądź większym stopniu, odkrywcze propozycje w zakresie konceptualizacji intelektualnej, uwzględniające zarówno kontekst synchroniczny, jak i diachroniczny ontologicznego oraz aksjologicznego wymiaru realiów polityki (Topolski, 1998, s. 37; Malczewski, 2009, s. $89-120)$.

Dociekania dotyczące implikacji teoretycznych w odniesieniu do całokształtu kwestii obejmujących sferę polityki mogą sprzyjać formułowaniu zdań na względnie wysokim poziomie ogólności, przy tym koherentnych w wymiarze merytorycznym oraz metodologicznym, a także w mniejszym bądź większym stopniu - adekwatnych do realiów społeczno-politycznych. Owych uogólnień nie należałoby artykułować ad hoc. Niemniej jednak prowadzenie dogłębnych dociekań na rzecz formułowania tego rodzaju konstatacji powinno sprzyjać osiąganiu pozytywnych rezultatów poznawczych uzyskujących odniesienia realizacyjne w zróżnicowanej aksjologicznie przestrzeni publicznej (Marcińczak, 2013). 
Artykułowane stanowiska zakładające trafność ontologiczną, aksjologiczną i funkcjonalną polityki w przestrzeni publicznej mogą zawierać wiele hipotez dotyczących uobecniających się prawidłowości w zakresie stosunków społeczno-politycznych i procesów politycznych. Nie sposób jednak owych hipotez uznawać za „twarde”, a więc bezalternatywne formuły myślowe odnoszone do sfery polityki, które byłyby uznawane za aksjomaty teoretyczne na gruncie politologii, ponieważ mogłoby to sprzyjać absolutyzacji formułowanych konstatacji politycznych. Oznacza to, że nie można nie być świadomym tego, iż uobecnianie się teorii politycznych $\mathrm{w}$ dyskursie publicznym nie powinno się stawać okolicznością sprzyjającą eksponowaniu formuł myślowych w zakresie stosunków społeczno-politycznych i procesów politycznych, uznawanych za niekwestionowane aksjomaty. Nie powinno to prowadzić do bezalternatywnej ideologizacji dociekań politologicznych $\mathrm{i}-\mathrm{w}$ ich następstwie - do pojawienia się niebezpieczeństwa „dogmatyzacji” określonych stwierdzeń, gdyż mogłoby dojść do uobecniania się tendencji na rzecz wykreowania jakiejś osobliwej gnozy ideologiczno-politycznej, niezgodnej z kryteriami naukowości (Voegelin, 1992; Bäcker, 1992; Bäcker, 1997, s. 5-14; Skoczyński, 1998). Znamienne jest to, iż uobecniają się niekiedy formuły myślowe określane mianem teologii politycznej (Schmitt, 2000).

Niezależnie od tego, co powiedziano wyżej, należy stwierdzić, iż politolodzy o różnych proweniencjach merytoryczno-poznawczych, a także inni przedstawiciele nauk humanistyczno-społecznych, reprezentujący wielorakie opcje metodologiczne oraz zajmujący się pogłębioną eksplanacją zjawisk i procesów politycznych mogą mieć sporo do powiedzenia w zakresie dociekań poznawczo-nomologicznych dotyczących takich czy innych teorii polityki.

\section{Teoria polityki jako następstwo uogólnień umożliwiających eksplanację osobliwości czasoprzestrzeni politycznej}

W następstwie konceptualizacji wielości teorii politycznych na jeszcze wyższym poziomie ogólności powinno dochodzić do sformułowania hipotez wzbogacających refleksję w zakresie teorii polityki. Tego rodzaju aktywności intelektualnej, umożliwiającej konceptualizację teoretyczną, powinny sprzyjać umiejętności w zakresie wielostronnego oraz pogłębionego oglądu poznawczego realiów polityki. Niezbędna jest zatem zdolność wykazania się inwencją pozwalającą na refleksję teoretyczną umożliwiającą wyjaśnianie stosunków społeczno-politycznych i procesów politycznych z uwzględnieniem - o ile to okazałoby się potrzebne - podejścia interdyscyplinarnego (Dudzikowa, Chmielewski, Grobler, 2012). 
Za konstatacje spełniające kryterium naukowości w sferze dociekań politologicznych, które byłyby zintegrowane w konceptualnej strukturze takiej czy innej teorii polityki, można by uznać hipotetyczny układ koherentnych uogólnień podlegających sprawdzalności w obecnych realiach politycznych. Tego rodzaju rozpoznanie prawidłowości o atrybutach prawdopodobieństwa, jeśli chodzi o osobliwości i zmienność „świata polityki”, cechowałoby dążenie na rzecz uzyskania optymalnej sprawczości w sferze stosunków politycznych i procesów politycznych z uwzględnieniem uwarunkowań sytuacyjnych (Clark, 1998).

Należy w związku z tym być świadomym, że nie zawsze adekwatne i innowacyjne konceptualizacje teoretyczne dotyczące określonych prawidłowości odnoszonych do sfery polityki oraz zjawisk polityzacji i polityczności mogą uzyskiwać mniejszą lub większą wyrazistość poznawczą oraz sprawdzalność w określonych realiach społecznych. Konstatacje, które cechuje wysoki poziom ogólności w zakresie prawdopodobieństwa i adekwatności odkrytych prawidłowości do praktyki politycznej, mogą się stawać, niezależnie od innych, istotnymi komponentami ujmowanej hipotetycznie teorii polityki, umożliwiającej wyjaśnienie osobliwości „świata polityki” w wymiarze holistyczno-diachronicznym (Krauz-Mozer, Ścigaj, 2013).

Za w znacznej mierze prawdopodobną należy uznać supozycję, iż teoretyczne rozważania dotyczące polityki, przyjmujące kształt zdań na wysokim poziomie ogólności, nieformułowanych ad hoc, wymagają pogłębionych przemyśleń. Powinny być one optymalnie koherentne pod względem konceptualno-teoretycznym, a także nieoderwane od realiów społeczno-politycznych określonego miejsca i czasu historycznego (Borowiec, 2013).

Prowadzone przez dłuższy czas przez politologów pogłębione komparatywne dociekania teoretyczno-politologiczne powinny sprzyjać formułowaniu zdań na najwyższym poziomie ogólności, a więc tak, aby były one ujęciami ideacyjnymi, które dotyczyłyby specyfiki wieloaspektowości realiów politycznych. Tego rodzaju innowacyjne ujęcia nomologiczne oparte na eksplanacji holistycznej i diachronicznej prowadziłyby do dalszej ideacji przyczyniającej się do optymalnie kreatywnego koncypowania adekwatnych uogólnień do realiów politycznych i - przy tym - także uniwersalnych konstatacji osiągających status hipotetycznych, o wysokim poziomie prawdopodobieństwa, formuł teoretyczno-politycznych (Johnson, Reynolds, Mycoff, 2010).

W trakcie formułowania zdań na wysokim poziomie ogólności dotyczących sfery polityki niezbędna jest niewątpliwie postawa otwarta, a zatem bez tendencji do bezkrytycznej aksjomatyzacji określonych konstatacji politycznych. Chodzi bowiem o podejście pozwalające na wieloaspektowe oraz pogłębione poznawanie istoty licznych prawidłowości dotyczących „świata polityki”. Nie musiałoby to oznaczać apriorycznego narzucania ustaleń teoretyczno-poli- 
tycznych uznawanych za niekwestionowane formuły, a więc za absolutnie prawdziwe zawsze i wszędzie. Toteż należałoby je uważać za propozycje intelektualne na rzecz wyjaśniania osobliwości realiów polityki i objawów polityczności, które muszą jednak podlegać permanentnej weryfikacji, jako że konieczne są nieprzerwany i pogłębiony ogląd i eksplanacja realiów politycznych (Ciunajcis, 2013, s. 153-180). Z tego względu za pozytywne mogą być uznawane dążenia kreatywne na rzecz formułowania uogólnień konceptualnych w zakresie teorii polityki, które nie byłyby oderwane od realiów politycznych oraz podlegałyby permanentnej sprawdzalności.

Odkrywanie i wyjaśnianie prawidłowości w kategoriach teorii polityki nie jest równoznaczne $\mathrm{z}$ formułowaniem pewników odnoszonych do realiów politycznych, ponieważ stymulowałoby to tendencję do aksjomatyzacji dociekań politologicznych. Konceptualizacje, które okazałyby się punktem odniesienia umożliwiającym kreowanie teorii polityki, nie powinny podlegać ideologizacji. Dlatego też należałoby uniemożliwić pojawienie się swego rodzaju gnozy ideologiczno-politycznej, której nie cechują jakiekolwiek atrybuty naukowości (Siemek, 1989, s. 13-27).

Doświadczenie komparatywne w zakresie nomologicznego wyjaśniania osobliwości polityki powinno stwarzać możliwość zainicjowania kontynuacji procesu ideacji politologicznej, sprzyjającej kreatywnemu formułowaniu konstatacji teoretycznych adekwatnych do całokształtu złożoności realiów polityki. Sprzyjałoby to podjęciu próby sformułowania hipotetycznego i jednocześnie optymalnego paradygmatu ${ }^{5} \mathrm{w}$ zakresie kreowania teorii polityki wobec zmiennych realiów społeczno-politycznych. Ów paradygmat powinien być komplementarny względem licznych specjalności nauk o polityce, których przedstawiciele wyrażają w mniejszym lub większym stopniu pragnienie formułowania konstatacji uzyskujących status stwierdzeń zintegrowanych w ramach takiej czy innej teorii polityki (Klementewicz, 2013, s. 164-189).

Oznacza to, iż jest możliwe formułowanie mniej lub bardziej adekwatnej do praktyki politycznej - aczkolwiek niekoniecznie uniwersalnej - teorii polityki, jednocześnie komplementarnej względem licznych specjalności nauk o polityce, których przedstawiciele mogą również tworzyć „aspekty” czy też „cząstko-

Przypomnijmy, iż słowo paradygmat zostało omówione przez Thomasa Kuhna w publikacji Struktura rewolucji naukowych (The Structure of Scientific Revolutions z 1962 r.). Wydania tej pracy w języku polskim ukazały się w 1986 oraz w 2001 r. Paradygmat rozumiany jest jako zbiór pojęć i teorii tworzących podstawy danej nauki i wzorów badawczych. Paradygmat przyjęty przez daną dyscyplinę nauki powinien być twórczy pod względem poznawczym, a zatem umożliwiać kreowanie teorii szczegółowych adekwatnych do tego, co się bada. Tę ogólną formułę można odnieść również do badań politologicznych, w tym także przedsięwzięć w zakresie poznawania, analizy i eksplanacji myśli politycznej. 
we" teorie niektórych relatywnie wąskich subdyscyplin nauk o polityce, takich jak np. „teoria stosunków międzynarodowych” (Borkowski, 2007; Czaputowicz, 2007), „teoria komunikacji politycznej” lub „teoria polityki historycznej” (Ponczek, 2011, s. 264-266; Ponczek, 2013, s. 7). Owe aspektowe teorie mogą być mniej lub bardziej adekwatne do takich lub innych odniesień wobec praktyki politycznej, która jest przedmiotem badań nauk o polityce oraz dociekań w zakresie ogólnej teorii polityki (Woleński, 1975, s. 32-34, 39, 45-48, 57; Woleński, 2014, s. 70-73).

\section{Refleksja końcowa}

W podsumowaniu powyższych rozważań należy zaproponować kilka istotnych konkluzji. Badanie myśli politycznej wielu nurtów ideologicznych i - co jest oczywiste - rozmaitych wykładni aksjologicznych przez relatywnie długi czas i jednocześnie $\mathrm{z}$ uwzględnieniem dyrektywy komparatywizmu powinno sprzyjać formułowaniu zdań ogólnych uzyskujących status ważnych konstatacji poznawczych oraz jednocześnie eksplanacyjnych, integrujących podstawowe pojęcia szeroko rozumianej polityki, polityzacji i polityczności. Umożliwiłoby to konceptualizację adekwatnych formuł teoretyczno-politologicznych sprawdzalnych w praktyce politycznej.

Doświadczenie multidyscyplinarne i komparatywne w zakresie nomologicznego wyjaśniania zjawisk i procesów politycznych oraz osobliwości polityzacji i polityczności można by uznać za punkt wyjścia do kreowania konstatacji teoretycznych odnoszonych do realiów politycznych i jednocześnie najlepiej sprawdzalnych w praktyce społeczno-politycznej. Stąd też niezbędna byłaby porównawcza analiza nomologiczna wielości teorii politycznych sprzyjająca konceptualizacji politologicznej, której istotą stałoby się stymulowanie wyobrażeń intelektualnych odzwierciedlonych w pojęciach politycznych i w hipotetycznych prawidłowościach dotyczących „świata polityki”.

Formułowanie stosownych uogólnień, uzyskujących status stwierdzeń odpowiadających standardom teorii polityki, powinno sprzyjać nomologicznej eksplanacji zjawisk i procesów politycznych. Tego rodzaju stwierdzenia podlegające dalszej konceptualizacji mogą wzbogacić dotychczasowe ustalenia w zakresie teorii politycznych, które powinny podlegać intelektualnemu uwiarygodnieniu. Dlatego też odkrywanie prawidłowości o znamionach probabilistycznych w odniesieniu do sfery polityki powinno być adekwatne do zmienności stosunków społeczno-politycznych oraz specyfiki procesów politycznych.

W związku z tym wskazana byłaby permanentna weryfikacja dotychczasowych konceptualizacji teoretycznych, wskutek czego możliwe byłoby kreatywne 
uaktualnianie dotychczasowych stwierdzeń politologicznych na wysokim poziomie ogólności. W konsekwencji dochodziłoby do odkrywania coraz to nowych probabilistycznych prawidłowości dotyczących osobliwości „świata polityki”.

Z powyższych względów wskazana jest stymulacja na rzecz wykreowania najbardziej racjonalnego, aczkolwiek hipotetycznego, paradygmatu badawczego teorii polityki, uwzględniającego wielość konceptualizacji w zakresie stosunków społeczno-politycznych oraz procesów politycznych. Ów paradygmat powinien być optymalnie komplementarny względem wielu specjalności nauk o polityce, których przedstawiciele nierzadko wykazują ambicje formułowania konstatacji uzyskujących status stwierdzeń o znamionach teoretycznych, mniej lub bardziej adekwatnych do rezultatów wieloaspektowego spektrum badań politologicznych.

\section{Literatura}

Bäcker, R. (1992). Totalitaryzm. Geneza, istota, upadek. Toruń: Index Books.

Bäcker, R. (1997). „Gnoza polityczna systemu totalitarnego”. W: R. Bäcker, P. Hübner (red.). Skryte oblicze systemu komunistycznego. U źródeł zła. Warszawa: Wydawnictwo DiG.

Bäcker, R., Wojtas, A., Lisiecki, M. (red.) (2008). Koncepcje modernizacji we wspótczesnej myśli politycznej. Toruń: Wydawnictwo Naukowe Uniwersytetu Mikołaja Kopernika.

Biały, F. (2012). „'Polityczność jako przedmiot poznania politologii”. Refleksje, nr 6.

Blok, Z., Kołodziejczak, M. (2015). „O statusie i znaczeniu kategorii polityki i polityczności w nauce o polityce". Studia Politologiczne, vol. 37.

Bonecki, M. (2011). „Interpretacja humanistyczna a teoretyczna rekonstrukcja kultury”. Filo-Sofija, nr 1.

Borkowski, P.J. (2007). Polityczne teorie integracji międzynarodowej. Warszawa: Centrum Doradztwa i Informacji „Difin”.

Borowiec, P. (2013). Czas polityczny po rewolucji. Czas w polskim dyskursie politycznym po 1989 roku. Kraków: Wydawnictwo Uniwersytetu Jagiellońskiego.

Braudel, F. (1999). Historia i trwanie, przeł. B. Geremek. Warszawa: Czytelnik.

Ciunajcis, D. (2013). „Czasoprzestrzeń dziejów. Transcendentalne warunki uprawiania historii jako polityki". Filo-Sofija, nr 20.

Clark, G. (1998). Przestrzeń, czas i człowiek: spojrzenie badacza prehistorii, przeł. H. Turczyn-Zalewska. Warszawa: PIW.

Czaputowicz, J. (2007). Teorie stosunków międzynarodowych: krytyka i systematyzacja. Warszawa: Wydawnictwo Naukowe PWN.

Dudzikowa, M., Chmielewski, A., Grobler, A. (2012). Interdyscyplinarnie o interdyscyplinarności: między ideą a praktyką. Kraków: Oficyna Wydawnicza „Impuls”. 
Duszak, A., Fairclough, N. (2008). Krytyczna analiza dyskursu. Interdyscyplinarne podejście do komunikacji społecznej. Kraków: Universitas.

Hudzik, J.P. (2014). „Kwestia interdyscyplinarności politologii”. W: R. Skarzyński (red.). Przedmiot poznania politologii. Podstawy dyscypliny nauki. Białystok: Temida 2.

Janusz, G. (2015). „Nauki o polityce i ich usytuowanie w systemie nauk”. Politeja, vol. 36. Jerzmanowska, A. (2013). „Empatia oraz decentracja interpersonalna a radykalność postaw społecznych”. Psychologia Społeczna, t. 8.

Johnson, J.B., Reynolds, H.I., Mycoff, J.D. (2010). Metody badawcze w naukach politycznych, przeł. A. Kloskowska-Dudzińska. Warszawa: Wydawnictwo Naukowe PWN.

Karwat, M. (2015a). „Metodologiczne dylematy i pułapki pojęcia polityczności”. Politeja, t. 36.

Karwat, M. (2015b). „O statusie pojęcia 'polityczności”. Studia Politologiczne, t. 37.

Klementewicz, T. (2010). „Rola wyjaśniania w rozumieniu działań i zjawisk politycznych". Studia Politologiczne, t. 17.

Klementewicz, T., (2013). „Politologia jako wieloparadygmatyczna struktura wiedzy”. E-Politicon, nr 5.

Krauz-Mozer, B. (2005). Teorie polityki. Założenia metodologiczne. Warszawa: Wydawnictwo Naukowe PWN.

Krauz-Mozer, B., Ścigaj, P. (red.) (2013). Podejścia badawcze i metodologiczne w nauce o polityce. Kraków: Księgarnia Akademicka.

Kucharczyk, G. (2009). Polska myśl polityczna po roku 1939. Dębogóra: Klub Książki Katolickiej.

Kuhn, T. (1986, 2001, 2009). Struktura rewolucji naukowych, przeł. H. Ostromęcka. Warszawa: Fundacja Aletheia.

Malczewski, M. (2009). „ «Metodologie» Jerzego Topolskiego”. Historyka, t. 39.

Marcińczak, Ł. (2013). Świat trzeba przekręcić. Rozmowy o imponderabiliach. Lublin: Norbertinum.

Nowak, P. (2014). Hodowanie troglodytów: uwagi o szkolnictwie wyższym i kulturze umysłowej człowieka współczesnego. Warszawa: Fundacja Augusta hrabiego Cieszkowskiego.

Ossowski, S. (1983). O osobliwościach nauk społecznych. Warszawa: PWN.

Paruch, W. (2004). „Między wyobrażeniami i działaniami. Wybrane aspekty przedmiotowe badań politologicznych nad myślą polityczną". Polityka i Społeczeństwo, nr 1.

Paruch, W. (2015). „Konsekwencje definiowania myśli politycznej dla kwestionariusza badań politycznych". Humanities and Social Sciences, t. 20, nr 1.

Ponczek, E. (2011). „Z myślą o integralnej refleksji teoretycznej w kwestii polityki historycznej”. W: Z. Blok (red.). Czym jest teoria w politologii? Warszawa: Dom Wydawniczy Elipsa.

Ponczek, E. (2013). „Polityka wobec pamięci versus polityka historyczna: aspekty semantyczny, aksjologiczny i merytoryczny w narracji polskiej”. Przegląd Politologicz$n y$, nr 2. 
Ponczek, E. (2015). „Style i wzorce badań myśli politycznej: od powierzchownej prezentacji do dogłębności oglądu nomologiczno-eksplanacyjnego”. Humanities and Social Sciences, t. XX, nr 3.

Ponczek, E. (2016). „Możliwości i ograniczenia podejścia interdyscyplinarnego w politologicznych badaniach myśli politycznej i refleksji teoretyczno-politycznej”. W: T. Domański (red.). Międzynarodowe studia polityczne i kulturowe wobec wyzwań współczesności. Łódź: Wydawnictwo Uniwersytetu Łódzkiego.

Schmitt, C. (2000). Teologia polityczna i inne pisma, przeł. M.A. Cichocki. Kraków: Znak. Siemek, M.J. (1989). „Nauka” i „naukowośc” jako ideologiczne kategorie filozofii. W: H. Kozakiewicz, E. Mokrzycki, M.J. Siemek (red.). Racjonalność. Nauka. Społeczeństwo. Warszawa: PWN.

Skarzyński, R. (2012). Podstawowy dylemat politologii: dyscyplina nauki czy potoczna wiedza o społeczeństwie? O tradycji uniwersytetu i demarkacji wiedzy. Białystok: Temida 2.

Skarzyński, R. (red.) (2014). Przedmiot poznania politologii. Podstawy dyscypliny nauki. Białystok: Temida 2.

Skoczyński, J. (red.) (1998). Gnoza polityczna. Kraków: Księgarnia Akademicka.

Topolski, J. (1998). Wprowadzenie do historii. Poznań: Wydawnictwo Poznańskie.

Trzebiński, J. (red.) (2002). Narracja jako sposób rozumienia świata. Gdańsk: Gdańskie Wydawnictwo Psychologiczne.

Ulicka, U. (2015). „Dlaczego pytanie o granice politologii jest ważne?”. Politeja, vol. 36.

Voegelin, E. (1992). Nowa nauka polityki, przeł. P. Śpiewak. Warszawa: Fundacja Aletheia.

Wallas, T. (2015). „Przyczynek do rozważań nad przynależnością dziedzinową nauk o polityce". Politeja, t. 36 .

Wojtaszczyk, K.A. (2015). „Granice nauki o polityce jako dyscypliny naukowej”. Politeja, t. 36.

Woleński, J. (1975). „Spór o status metodologiczny nauki o polityce”. W: K. Opałek (red.). Metodologiczne i teoretyczne problemy nauk politycznych. Warszawa: PWN.

Woleński, J. (2014). „Posłowie”. W: R. Skarzyński (red.). Przedmiot poznania politologii. Podstawy dyscypliny nauki. Białystok: Temida 2.

\section{Streszczenie}

Badania dotyczące osobliwości wieloaspektowości polityki, polityzacji i polityczności trwające przez dłuższy czas oraz z uwzględnieniem dyrektywy komparatywizmu - w zakresie zarówno myśli politycznej wielu nurtów ideologicznych i tym samym rozmaitych wykładni aksjologicznych, jak i podstawowych pojęć politologicznych - powinny zmierzać do formułowania zdań ogólnych uzyskujących status ważnych konstatacji eksplanacyjnych i nomologicznych umożliwiających kreowanie określonych teorii polityki.

Doświadczenie komparatywne w zakresie nomologicznego wyjaśniania zjawisk i procesów politycznych, a także wielorakich osobliwości polityczności powinno umożliwiać ideację politologiczną mogącą sprzyjać kreatywnemu formułowaniu twierdzeń teoretycznych w za- 
kresie prawidłowości ujętych probabilistycznie, odnoszących się do szeroko rozumianej polityki, sprawdzalnych w sytuacji zmieniających się realiów społeczno-politycznych.

Wskazana byłaby zatem wzmożona aktywność na rzecz sformułowania najbardziej adekwatnego paradygmatu konceptualnego w zakresie teorii polityki. Wskutek tego pojawiałyby się propozycje teorii polityki uwzględniającej realia społeczno-polityczne i komplementarnej względem licznych specjalności nauk o polityce. Ich przedstawiciele mogą wyrażać, w mniejszym lub większym stopniu, pragnienie formułowania konstatacji uzyskujących status stwierdzeń o znamionach teoretycznych, komplementarnych wobec dociekań i wyjaśniania w zakresie szerokiego spektrum badań politologicznych.

Słowa kluczowe: eksplanacja, polityka, teoria polityki, interdyscyplinarność, nauka o polityce 